\title{
Research
}

\section{Translation of clinical prediction rules for febrile children to primary care practice:}

\author{
an observational cohort study
}

\begin{abstract}
Background

Clinical prediction rules (CPRs) to identify

children with serious infections lack validation

in low-prevalence populations, which hampers their implementation in primary care practice.
\end{abstract}

Aim

To evaluate the diagnostic value of published CPRs for febrile children in primary care.

\section{Design and setting}

Observational cohort study among febrile children ( $<16$ years) who consulted five GP cooperatives (GPCs) in the Netherlands.

\section{Method}

Alarm signs of serious infection and clinical management were extracted from routine clinical practice data and manually recoded with a structured electronic data-entry program. Eight CPRs were selected from literature. CPR-variables were matched with alarm signs and CPRs were applied to the GPC-population. 'Referral to emergency department (ED)' was used as a proxy outcome measure for 'serious infection. CPR performance was assessed by calibration analyses, sensitivity, specificity, and area under the ROC-curve (ROC-area).

\section{Results}

A total of 9794 GPC-contacts were eligible,

$54 \%$ male, median age 2.3 years linterquartile range $1.0-4.6$ years) and $8.1 \%$ referred to ED. Frequencies of CPR-variables varied from $0.5 \%$ Icyanosis, drowsy) to $25 \%$ (temperature $\geq 40^{\circ} \mathrm{C}$. Alarm signs frequently included in CPRs were 'ill appearance', 'inconsolable', and 'abnormal circulatory or respiratory signs'. The height of the CPR's predicted risks generally corresponded with being (or not being) referred to the ED in practice. However, calibration-slopes indicated that three CPRs underestimated the risk of serious infection in the GPC-population. Sensitivities ranged from $42 \%$ to $54 \%$, specificities from $68 \%$ to $89 \%$. ROC-areas ranged from 0.52 to 0.81 , with best performance of CPRs for children aged $<3$ months.

\section{Conclusion}

Published CPRs performed moderately well in the primary out-of-hours care population. Advice is given on how to improve translation of CPRs to primary care practice.

\section{Keywords}

adolescent; bacterial infection; child, preschool; child; decision support techniques; fever; infant; primary health care.

\section{INTRODUCTION}

Most children who present to primary loutof-hours) care have fever as one of their main complaints. ${ }^{12}$ Febrile children are at risk of serious infections, such as meningitis or pneumonia, which are important causes of morbidity and mortality. ${ }^{3-5}$ However, the prevalence of serious infections in primary care is low ${ }^{6}$ and physicians have the challenging task of distinguishing children at high risk of serious infections from those with self-limiting disease. Only a few studies on the identification of serious infections in primary care have been published so far.6,7 Consequently, practice guidelines are mainly based on consensus of expert opinion and scientific evidence collected from secondary and tertiary emergency care studies. ${ }^{8.9}$ To complement practice guidelines, clinical prediction rules (CPRs) could be powerful tools to improve clinical decision making on the basis of combinations of clinical signs and symptoms. ${ }^{10}$ However, most published CPRs for serious infections have been developed predominantly at hospital emergency departments (EDs), ${ }^{11-13}$ with the lack of external validation in low-prevalence populations hampering their implementation in primary care practice. ${ }^{11,13,14}$ The present study aimed to assess the applicability and diagnostic value of published CPRs for serious infections in febrile children

Y van lerland, PhD, MD, geneticist in training H A Moll, MD professor and pediatrician; R Oostenbrink, $\mathrm{PhD}, \mathrm{MD}$, pediatrician,

Department of General Paediatrics, ErasmusMC - Sophia Children's Hospital, University Medical Center Rotterdam, Rotterdam, the Netherlands. G Elshout, MD, GP in training Department of General Practice; Y Vergouwe $\mathrm{PhD}$, methodologist, Center for Medical Decision Making: M de Wilde, BSc, scientific programmer: J van der Lei, professor, head of Department of Medical Informatics, ErasmusMC, University Medical Center Rotterdam, Rotterdam, the Netherlands. M Y Berger, MD, professor and GP, Department of General Practice, University Groningen, University Medical Center Groningen, consulting primary out-of-hours care.

\section{METHOD}

\section{Study design}

As part of an observational study, semistructured, routine clinical practice data were prospectively collected on children who had presented to out-of-hours primary care lworkdays from $5 \mathrm{pm}$ to $8 \mathrm{am}$, and the entire weekendl with fever. The diagnostic value of published CPRs for serious infections was assessed, defining 'referral to ED' as the outcome measure.

\section{Study setting and selection of patients}

The out-of-hours healthcare system in the Netherlands and data collection of this study have been published previously. ${ }^{15}$ In summary, all contacts of children $<16$ years that had taken place at five GP cooperatives (GPCs) of the Rotterdam Rijnmond-district (collaboration of $>250$ GP-practices) between March 2008 and February 2009 were selected. Eligible contacts were those concerning children who had a face-to-face consultation with the GP and reported fever as the reason for contact, had fever within the 24 hours before contact, or had a (rectal or tympanic) temperature $>38^{\circ} \mathrm{C}$ measured at the GPC. Re-contacts for the same problem within 7 days of the initial presentation were excluded from the main analyses.

Groningen, the Netherlands. Address for correspondence

Rianne Oostenbrink, Department of General Paediatrics, ErasmusMC - Sophia Children's Hospital, University Medical Center Rotterdam, PO Box 2060, 3000 CB, Rotterdam, the Netherlands.

E-mail: r.oostenbrinkderasmusmc.nl Submitted: 2 June 2014; Editor's response: 23 June 2014; final acceptance: 28 July 2014. (c)British Journal of General Practice

This is the full-length article (published online 30 Mar 2015) of an abridged version published in print. Cite this article as: Br J Gen Pract 2015; DOI: 10.3399/bjgp15X684373 


\section{How this fits in}

Published clinical prediction rules (CPRs) to identify children with serious infections lack validation in low-prevalence populations, which hampers their implementation in primary care practice. The present study shows that published CPRs perform only moderately well in the primary out-of-hours care population with limited rule-out value. Improved translation of CPRs to primary out-of-hours care could be achieved by the introduction of structured documentation of vital signs, application of inflammatory marker point-of-care tests, introduction of follow-up contacts, and the identification of predictors with diagnostic value in the primary care setting specifically.

\section{Extraction of relevant clinical signs}

Clinical features indicative of serious infections were derived from one systematic review $^{12}$ and two published guidelines on management of febrile children. ${ }^{8,16}$ Features were included that:

- had a high predictive value (positive likelihood ratio $>5.0$ or negative likelihood ratio $<0.2$ ) ;

- were mentioned in at least two of the three data sources:

- did not represent a diagnosis; and

- were not prone to high inter-observer variability (for example, auscultatory sounds). ${ }^{17}$

The selected features were grouped into 18 'alarm signs' (Appendix 1). For eligible contacts, it was manually recoded whether alarm signs were 'present', 'absent', or 'not mentioned' in the patient record, using the data-entry computer program Embarcadero Delphi XE (version 15.0). Clinical management by the GP was recoded as 'referral to ED', 'follow-up appointment at GP(C)', or 'no follow-up'.

\section{Table 1. Overview of selected clinical prediction rules}

\begin{tabular}{|c|c|c|c|c|c|c|c|c|}
\hline $\begin{array}{l}\text { Clinical } \\
\text { prediction rule }\end{array}$ & $\begin{array}{c}\text { Year of } \\
\text { publication }\end{array}$ & $\begin{array}{l}\text { Country of } \\
\text { derivation }\end{array}$ & Setting & Model & Age & $\begin{array}{c}\text { Patients, } \\
n\end{array}$ & $\begin{array}{c}\text { Serious } \\
\text { infections, \% }\end{array}$ & CPR variables \\
\hline \multicolumn{9}{|c|}{ High/Low risk prediction } \\
\hline 1. Van den Bruel et $a l^{6}$ & 2007 & Belgium & Primary & CART & $0-16$ years & 3981 & 0.8 & $\begin{array}{l}\text { Clinician's instinct something } \\
\text { is wrong, dyspnoea, temperature, } \\
\text { age, diarrhoea }\end{array}$ \\
\hline 2. Thompson et al ${ }^{18}$ & 2009 & UK & Secondary & High/low & $\begin{array}{l}3 \text { months } \\
-16 \text { years }\end{array}$ & 527 & 15 & $\begin{array}{l}\text { Temperature, oxygen saturation } \\
\leq 94 \% \text {, tachypnoea, tachycardia }\end{array}$ \\
\hline 3. Pantell et al ${ }^{19}$ & 2004 & $\begin{array}{l}\text { US, Colombia, } \\
\text { Puerto Rico }\end{array}$ & $\begin{array}{c}\text { Paediatric } \\
\text { practices/secondary }\end{array}$ & CART & $<3$ months & 3066 & 2.9 & Age, ill appearance, temperature \\
\hline \multicolumn{9}{|c|}{ Continuous risk prediction } \\
\hline 4. Pantell et al ${ }^{19}$ & 2004 & $\begin{array}{l}\text { US, Colombia, } \\
\text { Puerto Rico }\end{array}$ & $\begin{array}{c}\text { Paediatric } \\
\text { practices/secondary }\end{array}$ & MLRM & $<3$ months & 3066 & 2.9 & $\begin{array}{l}\text { Age, ill appearance, temperature, } \\
\text { abnormal cry, Medicaid } \\
\text { insurance, ill family members, } \\
\text { inner-city clinic, URTI diagnosed }\end{array}$ \\
\hline 5. Bleeker et $a l^{20}$ & 2007 & Netherlands & Secondary & MLRM & 1-36 months & 381 & 27 & $\begin{array}{l}\text { Ill clinical appearance, poor } \\
\text { peripheral circulation, chest } \\
\text { wall retractions } \pm \text { tachypnoea, } \\
\text { duration of fever, history of vomiting }\end{array}$ \\
\hline 6. Berger et al ${ }^{21}$ & 1996 & Netherlands & Secondary & MLRM & $\begin{array}{l}2 \text { weeks } \\
-1 \text { year }\end{array}$ & 138 & 24 & $\begin{array}{l}\text { Clinical impression, duration of fever } \\
>48 \text { hours, history of diarrhoea, CRP }\end{array}$ \\
\hline 7. YICSSG 22 & 2008 & $\begin{array}{l}\text { Bangladesh, } \\
\text { Bolivia, } \\
\text { Ghana, India, } \\
\text { Pakistan, } \\
\text { South Africa }\end{array}$ & $\begin{array}{l}\text { Secondary (mimic } \\
\text { primary care) }\end{array}$ & MLRM & $<2$ months & 8889 & $7-70$ & $\begin{array}{l}\text { Cyanosis, temperature, prolonged } \\
\text { capillary refill, movement on } \\
\text { stimulation only, tachypnoea, severe } \\
\text { chest indrawings, history of } \\
\text { convulsions, stiff limbs, history of } \\
\text { difficulty feeding, lethargic, grunting }\end{array}$ \\
\hline 8. Brent et $a l^{23}$ & 2011 & UK & Secondary & MLRM & $\begin{array}{l}1 \text { months } \\
-15 \text { years }\end{array}$ & 1951 & 4 & $\begin{array}{l}\text { State variation, temperature, } \\
\text { capillary refill } \geq 2 \text { seconds, } \\
\text { hypoxia, tachypnoea, dehydration, } \\
\text { history of developmental delay, } \\
\text { risk factor for infection (comorbidity) }\end{array}$ \\
\hline
\end{tabular}




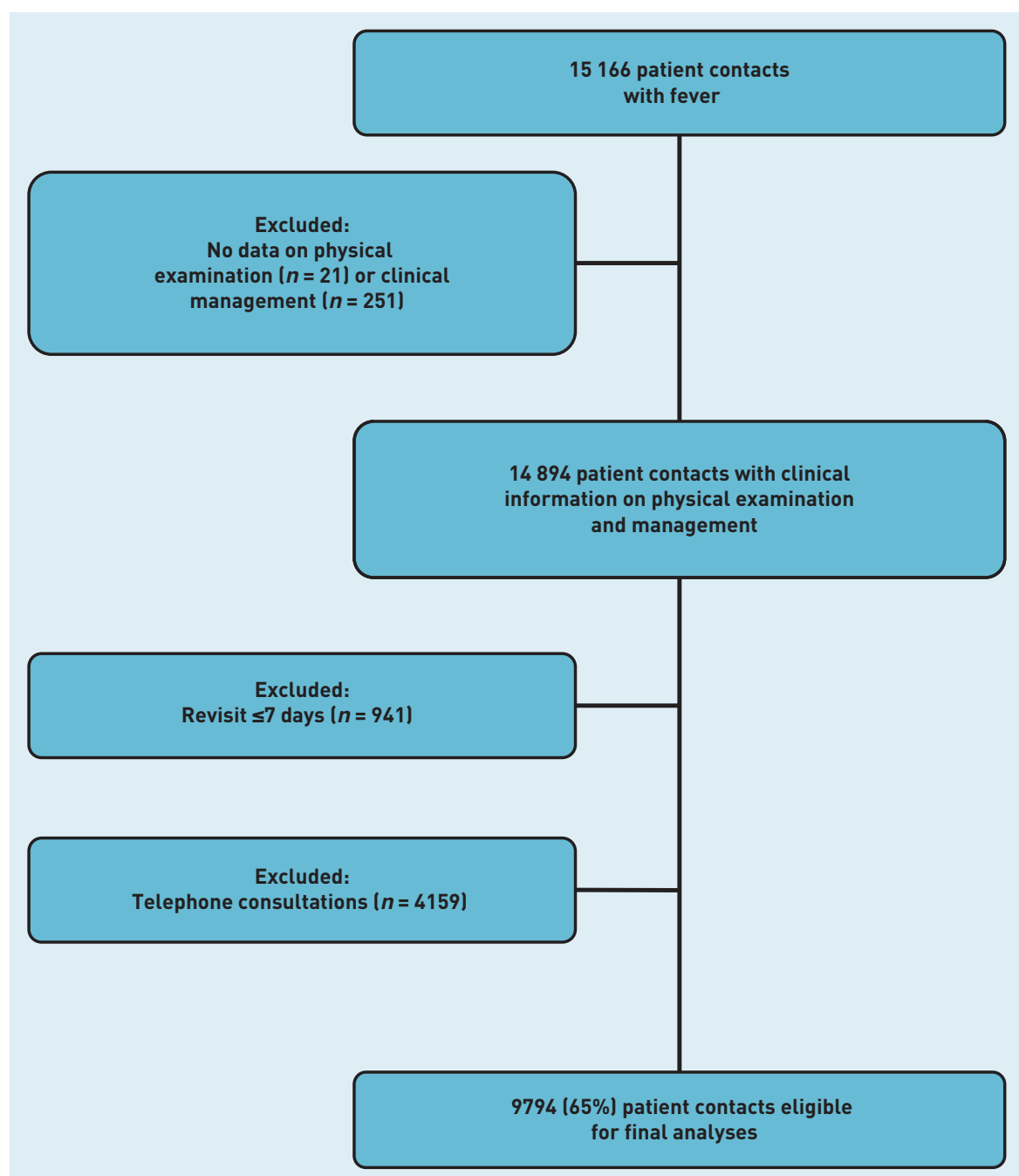

Figure 1. Selection of eligible contacts.

\section{Selection of CPRs and translation to the primary out-of-hours care population}

Eligible CPRs were selected on the basis of two important reviews on this topic, ${ }^{11,12}$ and an additional literature search of published CPRs for serious infections in children (published between 1975 and 2012, and relevant to developed countries; Appendix 2). Selected CPRs were deemed to:

- have clinical signs and symptoms as predictors;

- have no more than one laboratory test as a predictor variable, because these are unavailable at the GPC;

- have a composite outcome of serious infections; and

- advise on management strategies or give a risk score.

Eight of 32 CPRs extracted from literature were included in the final analyses (Table 1).6,18-23 Variables of the selected CPRs were matched with the alarm signs in the GPC-dataset. In case alarm signs were not entirely identical to the original CPR variables, best proxy variables were used. When CPR variables were missing in the GPC-dataset, it was assumed these were absent.

The unavailability of data on exact diagnoses hampered the verification of outcome diagnoses in the routine clinical practice dataset. As in primary care, identification of febrile children at risk of a serious infection (that is, requiring specialist assessment) is often more important than confirming the exact diagnosis, ${ }^{14,24}$ 'referral to ED' was used as a proxy for 'serious infection'. This proxy was validated among a subset of GP-referred febrile children who presented to the ED of the nearby Sophia Children's Hospital during the outof-hours period (January 2006 to July 2009; $N=376) .{ }^{25}$ It was observed that $66 \%$ of these GP-referred children required some form of extensive diagnostic interventions (such as, blood culture or lumbar puncture), extensive therapeutic interventions (such as, intravenous [IV]-medication or aerosol treatment), or hospitalisation, indicating the presence of a serious febrile illness. Only 395 (4\%) of 9794 GPC-contacts had a second contact for the same complaint within 7 days, of which $67(0.7 \%)$ were referred to the ED. Figures were comparable for children who had or had not been prescribed antibiotics at first consultation.

\section{Missing data}

As clinical information was obtained from routine practice data, there were some missing values. A consensus-meeting with one GP, two paediatricians, and two residents (general practice and paediatrics) decided, for the purpose of this study, to deal with missing values in two way. As GPs are taught to recognise alarm signs in febrile children, it was assumed that alarm signs were always documented when present and, consequently, when alarm signs were 'not mentioned' in the patient record, these were considered to be 'absent'. Also for continuous variables (such as, temperature and duration of fever), missing values were replaced by mean values.

\section{Statistical analyses}

Patient characteristics and frequencies of alarm signs were analysed using descriptive statistics. For some CPRs based on multivariable logistic regression models, two separate but closely related variables were combined into one alarm sign (such as 'tachypnoea' and 'chest wall retractions' into 'shortness of breath') or categorical 
Table 3. Model predictors used and frequencies in the GPC-population

\section{Study population}

\begin{tabular}{|c|c|c|}
\hline \multirow{2}{*}{ Derivation-population } & \\
\hline & Variables/proxies & requency of presence, $\%$ \\
\hline 1. Van den Bruel et $a l^{6}$ & & (0-16 years: $n=9794)$ \\
\hline Clinician instinct something is wrong & III appearance & 4.0 \\
\hline Dyspnoea & Shortness of breath & 4.7 \\
\hline Temperature $\geq 39.95^{\circ} \mathrm{C}$ & Temperature $\geq 40^{\circ} \mathrm{C}$ & 25.1 \\
\hline Age between $1.18-2.42$ years & Age between $1.18-2.42$ years & 22.4 \\
\hline Diarrhoea & Vomiting and diarrhoea & 21.2 \\
\hline 2. Thompson et al ${ }^{18}$ & $13 \mathrm{~m}$ & nonths- 16 years: $n=9590$ ) \\
\hline Temperature $\geq 39.0^{\circ} \mathrm{C}$ & Temperature $\geq 39.0^{\circ} \mathrm{C}$ & 11.5 \\
\hline Oxygen saturation $\leq 94 \%$ & Cyanosis & 0.5 \\
\hline Tachypnoea (APLS) & Shortness of breath & 4.7 \\
\hline Tachycardia (APLS) & Abnormal circulation & 1.6 \\
\hline 3. Pantell et al ${ }^{19}$ & & (<3 months: $n=204$ ) \\
\hline Age $<25$ days & Age $<25$ days & 12.3 \\
\hline Ill appearance & Ill appearance & 2.5 \\
\hline Temperature $\geq 38.6^{\circ} \mathrm{C}$ & Temperature $\geq 38.6^{\circ} \mathrm{C}$ & 14.7 \\
\hline 4. Pantell et $a l^{19}$ & & (<3 months: $n=204$ ] \\
\hline Age $\leq 30$ days & Age $\leq 30$ days & 14.7 \\
\hline Age $31-60$ days & Age $31-60$ days & 39.2 \\
\hline Ill appearance & Ill appearance & 2.5 \\
\hline Temperature $38.5-38.9^{\circ} \mathrm{C}$ & Temperature $38.5-38.9^{\circ} \mathrm{C}$ & 10.8 \\
\hline Temperature $39.0-39.4^{\circ} \mathrm{C}$ & Temperature $39.0-39.4^{\circ} \mathrm{C}$ & 5.9 \\
\hline Temperature $\geq 39.5^{\circ} \mathrm{C}$ & Temperature $\geq 39.5^{\circ} \mathrm{C}$ & 1.0 \\
\hline Abnormal cry & Inconsolable & 22.5 \\
\hline Medicaid insurance & $\mathrm{n} / \mathrm{a}$ & $\mathrm{n} / \mathrm{a}$ \\
\hline Ill family members & $\mathrm{n} / \mathrm{a}$ & $\mathrm{n} / \mathrm{a}$ \\
\hline Inner-city clinic & $\mathrm{n} / \mathrm{a}$ & $\mathrm{n} / \mathrm{a}$ \\
\hline Upper respiratory tract infection diagnosed & $\mathrm{n} / \mathrm{a}$ & $\mathrm{n} / \mathrm{a}$ \\
\hline
\end{tabular}

Upper respiratory tract infection diagnosed

\section{Bleeker et $a^{20}$}

Ill clinical appearance

Poor peripheral circulation

Chest wall retractions \pm tachypnoea

Duration of fever (days)

History of vomiting

\section{Berger et al}

Clinical impression

Duration of fever $>48$ hours

History of diarrhoea

C-reactive protein

7. Young Infants Clinical Signs Study Group ${ }^{22}$

Cyanosis

Temperature $<35.5^{\circ} \mathrm{C}$

Temperature $\geq 37.5^{\circ} \mathrm{C}$

Prolonged capillary refill

Movement on stimulation only

Lethargic

Tachypnoea

Severe chest indrawings

History of convulsions

Stiff limbs

History of difficulty feeding

Grunting

\section{Brent et $a^{23}$}

State variation category

Temperature $\geq 37.5-38.4$

Temperature $\geq 38.5$

Capillary refill $\geq 2$ seconds

Hypoxia category

Tachypnoea

Dehydration category

History of developmental delay

Risk factor for infection (comorbidity) the GPC-population than in the derivationpopulation (Appendix 3). Sensitivities of CPRs $1-3$ ranged from $42 \%$ to $54 \%$, and were lower than those reported in derivation settings. In contrast, specificities of CPRs 2 and 3 were higher (>86\% versus $39 \%$ and $35 \%$ at derivation), as were positive and negative likelihood ratios (Table 4). Discriminative abilities of CPRs 4-8 varied widely, but were to some extent comparable with ROC-areas reported in the derivation studies (Table 5). CPR 6 had the lowest ROC-area of 0.52, whereas the two rules developed for young children showed the best discriminative abilities with ROC-areas of 0.77 (CPR 4) and 0.81 (CPR 7).

\section{DISCUSSION}

\section{Summary}

The present study demonstrated that published CPRs for serious infections, mainly derived at hospital EDs, performed only moderately well in the primary out-ofhours care setting using 'referral to ED' as the outcome measure. Most CPR variables were observed to be reported positively in a low frequency in the GPC-population. Limited rule-out value was found for CPRs that classified children into highor low-risk groups. Use of CPRs which gave a continuous risk prediction was too moderate to be directly applicable to clinical primary care practice.

\section{Strengths and limitations}

This study is the first to assess the diagnostic value of several published CPRs for serious infections in an urban, multi-ethnic, out-ofhours primary care cohort of nearly 10000 contacts of febrile children. It is anticipated that these results will be valuable to many other countries where primary care is provided by GPs or where out-of-hours care has similarly shifted towards largescale cooperatives. ${ }^{26}$ As prospective studies on serious infections in low prevalence settings are logistically challenging and time consuming, routine clinical practice data were used in this study. Consequently, the results should be considered in the context of some difficulties and limitations elicited by this 'second best' approach. 14,24

First, 'referral to ED' was used as a proxy outcome measure for 'serious infection'. It is acknowledged that using a differently defined, although well-correlated, outcome measure may be suboptimal and may have resulted in an overestimation of the prevalence of serious infections in the study population (for example, reflected by calibration slopes $>1$ ). For each of the selected CPRs, however, 'serious infection' 
Table 4. Performance of clinical prediction rules with a high/low risk prediction (CPRs 1-3)

\begin{tabular}{|c|c|c|c|c|c|c|}
\hline Clinical prediction rule & $\begin{array}{c}\text { SI/referral among } \\
\text { High-risk, \% }\end{array}$ & $\begin{array}{l}\text { SI/referral among } \\
\text { Low-risk, \% }\end{array}$ & $\begin{array}{l}\text { Sensitivity } \\
\%(95 \% \mathrm{Cl})\end{array}$ & $\begin{array}{l}\text { Specificity } \\
\%(95 \% \text { CI) }\end{array}$ & $\mathrm{LR}+(95 \% \mathrm{CI})$ & LR- $(95 \% \mathrm{CI})$ \\
\hline \multicolumn{7}{|l|}{ 1. Van den Bruel et $a l^{6}$} \\
\hline Derivation-population ( $n=3981$ ) & 6 & 0.03 & 97 (83 to 100) & 89 (88 to 90) & 8.4 (7.6 to 9.4$)$ & $0.04(0.01$ to 0.2$)$ \\
\hline GPC-population ( $n=9794)$ & 13 & 6 & 54 (50 to 57) & $68(67$ to 69$)$ & $1.7(1.6$ to 1.8$)$ & 0.7 (0.6 to 0.7 ) \\
\hline \multicolumn{7}{|l|}{ 2. Thompson et al ${ }^{18}$} \\
\hline Derivation-population ( $n=527)$ & 54 & 31 & 80 (75 to 85$)$ & 39 (34 to 44 ) & 1.3 (1.2 to 1.5$)$ & 0.5 (0.4 to 0.7$)$ \\
\hline GPC-population ( $n=9590)$ & 22 & 4 & 50 (47 to 54) & 86 (85 to 87 ) & 3.6 (3.3 to 3.9 ) & $0.6(0.5$ to 0.6$)$ \\
\hline \multicolumn{7}{|l|}{ 3. Pantell et al ${ }^{19}$} \\
\hline Derivation-population ( $n=3066$ ) & 3 & 0.4 & 94 (84 to 98 ) & 35 (33 to 37) & 1.4 (1.3 to 1.5$)$ & 0.2 (0.1 to 0.5 ) \\
\hline GPC-population ( $n=240)$ & 78 & 38 & 42 (33 to 53) & 89 (81 to 94) & 3.7 (2.1 to 6.6$)$ & 0.7 (0.5 to 0.8 ) \\
\hline
\end{tabular}

$G P C=G P$ cooperative. $L R-=$ negative likelihood ratio. $L R+=$ positive likelihood ratio. $N=$ number of contacts. $S I=$ serious infection.

\section{Table 5. Performance of clinical prediction rules with continuous risk prediction (CPRs 4-8)}

\begin{tabular}{|c|c|c|}
\hline Clinical prediction rule & Calibration slope & ROC-area $(95 \% \mathrm{CI})$ \\
\hline \multicolumn{3}{|l|}{ 4. Pantell et al ${ }^{19}$} \\
\hline Derivation population $(n=3066)$ & & 0.82 (n/a) \\
\hline GPC-population $(n=204)$ & 1.44 & $0.77(0.71$ to 0.84$)$ \\
\hline \multicolumn{3}{|l|}{ 5. Bleeker et $a l^{20}$} \\
\hline Derivation population ( $n=381)$ & & 0.69 (0.63 to 0.75$)$ \\
\hline GPC-population ( $n=5809)$ & 0.82 & $0.65(0.62$ to 0.67$)$ \\
\hline \multicolumn{3}{|l|}{ 6. Berger et al ${ }^{21}$} \\
\hline Derivation population ( $n=138$ ) & & $\mathrm{n} / \mathrm{a}$ \\
\hline GPC-population ( $n=2382)$ & 0.17 & $0.52(0.49$ to 0.56$)$ \\
\hline \multicolumn{3}{|c|}{ 7. Young Infants Clinical Signs Study Group ${ }^{22}$} \\
\hline Derivation population ( $n=8889$ ) & & $\mathrm{n} / \mathrm{a}$ \\
\hline GPC-population $(n=114)$ & 2.00 & 0.81 (0.73 to 0.89$)$ \\
\hline \multicolumn{3}{|l|}{ 8. Brent et $a l^{23}$} \\
\hline Derivation population ( $n=1951$ ) & & 0.77 (0.71 to 0.83 ) \\
\hline GPC-population ( $n=9762)$ & 2.05 & 0.71 (0.69 to 0.73 ) \\
\hline
\end{tabular}

$G P C=G P$ cooperative. $n / a=$ not available. $R O C$-area $=$ area under the receiver operating characteristic curve YICSSG = Young Infants Clinical Signs Study Group of 'missingness' may be diverse, missing values were replaced on the basis of clinical rationale for the purpose of this study. To evaluate potential bias arising from this approach, sensitivity analyses were performed with missing values imputed on the basis of correlations between missing values and available information of other variables. ${ }^{27}$ For CPRs 4-8, these secondary analyses showed similar ROC-areas but calibration slopes closer to 1 (that is, better model fit). For CPRs 2 and 3, particular higher sensitivities were observed $173 \%$ and $62 \%$, respectively) and lower negative likelihood ratios (0.4 and 0.6, respectively), which indicates that the main analyses may 'err' on the safe side by underestimating rather than overestimating the CPR's performances.

\section{Comparison with existing literature}

The present finding that most CPRs performed only moderately well in the low prevalence setting may, next to the methodological limitations of this study, be explained by the specific characteristics of primary care practice itself. GPs constantly have to balance the risk of missing a serious infection versus unnecessary referral.? This difficulty particularly accounts for children with an unclear presentation ('grey area'), ${ }^{14}$ which was previously demonstrated in studies among children hospitalised for meningococcal disease ${ }^{28-31}$ and malpractice lawsuits. ${ }^{32,33}$ Clinical decision support by CPRs may be helpful in this diagnostic dilemma; however, in the low prevalence setting, high rule-out value should be achieved to reduce the number of false negative patients. ${ }^{7,24}$ Unfortunately, in this study it was shown that the published CPRs which predicted a high or low risk of serious infection showed insufficient rule-out value llow sensitivities and high 
negative likelihood ratios). Most CPRs that gave a continuous risk prediction could not discriminate well between the middle percentile-groups of the predicted risk, and observed referral frequencies varied considerably (Appendix 3).

Possible explanations for this discrepancy in performance of CPRs at the GPC and ED, may be that in the primary care setting observed frequencies of CPR variables are low, vital signs are barely measured, ${ }^{34}$ and additional diagnostic tests, such as inflammatory markers, are unavailable. These issues reduced the heterogeneity of CPR variable outcomes, and thus of the predicted risks for each patient in the GPC population (that is, less spread of the predicted risks). Unavailability of predictor variables in the GPC setting may have negatively influenced the performance of some CPRs more than others. Also, some predictor variables are likely to be better predictors of serious infection in the $\mathrm{ED}$ setting than the GPC setting.

Unfortunately, the only CPR derived in a primary care setting itself ${ }^{b}$ showed no diagnostic value in the present GPCpopulation. Previously, others had also demonstrated only marginal rule-out value for this CPR, ${ }^{13,35}$ which further underscores the importance of external validation before implementation in clinical practice..$^{10,14}$

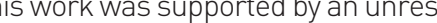
grant from Europe Container Terminals B.V. The funder had no role in study design, the collection, analyses or interpretation of data, writing the report or the decision to submit the manuscript for publication. Rianne Oostenbrink is supported by a personal grant of the European Society for Paediatric Infectious Diseases (ESPID Fellowship 2009).

\section{Ethical approval}

The institution's medical ethics committee reviewed the study and the requirement for informed consent was waived (MEC2012-378).

\section{Provenance}

Freely submitted; externally peer reviewed.

\section{Competing interests}

The authors have declared no competing interests.

\section{Acknowledgements}

We acknowledge EJ van Dijk for providing the data collected at the GPC and thank $T$ Krecinic, Z Gocmen, M Hofhuis, and M Rotsteeg for their contribution to the data management of this study.

\section{Discuss this article}

Contribute and read comments about this article: bjgp.org/letters

\section{Implications for research and practice}

How do the present results support the translation of existing CPRs to primary care settings? Given the importance of vital signs in most CPRs, structured vital sign measurements at GPCs would be advised. The present study suggests that published CPRs should be updated with variables available in and relevant to the primary care setting..$^{36}$ In this way, CPRs may better discriminate between seriously ill children and those in the 'grey area' who have a less clear clinical presentation. The strong diagnostic value of inflammatory markers, as already demonstrated in adult primary care, ${ }^{37-39}$ may favour their implementation in primary care practice to further improve diagnostic discrimination. However, it should be noted that no inflammatory marker has perfect discriminative ability on its own and clinical observation remains essential las is reflected by CPRs combining clinical variables with inflammatory markers). Finally, a follow-up period after the initial GPC-contact could contribute to differentiation between evolving serious infections from self-limiting viral disease.

In light of the methodological difficulties, the present study shows that published CPRs performed moderately well in the primary out-of-hours care population with limited rule-out value. Most CPR variables were observed to be reported positively in a low frequency in the GPC-population. Improved translation of CPRs to primary out-of-hours care could be achieved by introduction of structured documentation of vital signs, application of inflammatory marker point-of-care tests, introduction of follow-up contacts, and identification of predictors with diagnostic value in the primary care setting specifically. 


\section{REFERENCES}

1. Moll van Charante EP, van Steenwijk-Opdam PC, Bindels PJ. Out-of-hours demand for GP care and emergency services: patients' choices and referrals by general practitioners and ambulance services. BMC Fam Pract 2007; 8: 46.

2. Bruijnzeels MA, Foets M, van der Wouden JC, et al. Everyday symptoms in childhood: occurrence and general practitioner consultation rates. $\mathrm{Br} J \mathrm{Gen}$ Pract 1998; 48(426): 880-884

3. Bateman SL, Seed PC. Procession to pediatric bacteremia and sepsis: covert operations and failures in diplomacy. Pediatrics 2010; 126(1): 137-150.

4. Prayle A, Atkinson M, Smyth A. Pneumonia in the developed world. Paediatr Respir Rev 2011; 12(1): 60-69.

5. Saez-Llorens $X$, McCracken GH, Jr. Bacterial meningitis in children. Lancet 2003; 361(9375): 2139-2148

6. Van den Bruel A, Aertgeerts B, Bruyninckx R, et al. Signs and symptoms for diagnosis of serious infections in children: a prospective study in primary care. Br J Gen Pract 2007; 57(540): 538-546.

7. Thompson MJ, Harnden A, Del Mar C. Excluding serious illness in feverish children in primary care: restricted rule-out method for diagnosis. BMJ 2009; 338: b1187

8. Berger MY, Boomsma LJ, Albeda FW, et al. Guideline. Children with fever [NHG-standaard Kinderen met koorts] 2008. http://nhg.artsennet.nl/ kenniscentrum/k_richtlijnen/k_nhgstandaarden/SamenvattingskaartjeNHGStandaard/M29_svk.htm laccessed 13 Feb 2014).

9. National Institute for Health and Care Excellence. Feverish illness in children. May 2013. http://guidance.nice.org.uk/CG160 laccessed 27 Nov 2014).

10. Reilly BM, Evans AT. Translating clinical research into clinical practice: impact of using prediction rules to make decisions. Ann Intern Med 2006 144(3): 201-209.

11. Maguire JL, Kulik DM, Laupacis A, et al. Clinical prediction rules for children: a systematic review. Pediatrics 2011; 128(3): e666-e677.

12. Van den Bruel A, Haj-Hassan T, Thompson M, et al. Diagnostic value of clinical features at presentation to identify serious infection in children in developed countries: a systematic review. Lancet 2010; 375(9717): 834-845.

13. Thompson M, Van den Bruel A, Verbakel J, et al. Systematic review and validation of prediction rules for identifying children with serious infections in emergency departments and urgent-access primary care. Health Technol Assess 2012; 16(15): 1-100.

14. Oostenbrink R, Thompson M, Steyerberg EW; ERNIE members. Barriers to translating diagnostic research in febrile children to clinical practice: a systematic review. Arch Dis Child 2012; 97(7): 667-672.

15. Elshout $G$, van lerland $Y$, Bohnen AM, et al. Alarm signs and antibiotic prescription in febrile children in primary care: an observational cohort study. Br J Gen Pract 2013; DOI: 10.3399/bjgp13X669158.

16. National Institute for Health and Care Excellence. Feverish illness in children Assessment and initial management in children younger than 5 years. May 2007. http://uww.nice.org.uk/CG047 (accessed 27 Nov 2014).

17. Muris JWM. Lung auscultation in general practice. A literature survey. [in Dutch]. Huisarts Wet 1990; 33(7): 258-262.

18. Thompson M, Coad N, Harnden A, et al. How well do vital signs identify children with serious infections in paediatric emergency care? Arch Dis Child 2009: 94(11): 888-893.

19. Pantell RH, Newman TB, Bernzweig J, et al. Management and outcomes of care of fever in early infancy. JAMA 2004; 291(10): 1203-1212.

20. Bleeker SE, Derksen-Lubsen G, Grobbee DE, et al. Validating and updating a prediction rule for serious bacterial infection in patients with fever without source. Acta Paediatr 2007; 96(1): 100-104.

21. Berger RM, Berger MY, van Steensel-Moll HA, et al. A predictive model to estimate the risk of serious bacterial infections in febrile infants. Eur $J$ Pediatr 1996; 155(6): 468-473.

22. Young Infants Clinical Signs Study Group (YICSSG). Clinical signs that predic severe illness in children under age 2 months: a multicentre study. Lancet 2008; 371(9607): 135-142

23. Brent AJ, Lakhanpaul M, Thompson M, et al. Risk score to stratify children with suspected serious bacterial infection: observational cohort study. Arch Dis Child 2011; 96(4): 361-367.

24. Buntinx F, Mant D, Van den Bruel $A$, et al. Dealing with low-incidence serious diseases in general practice. Br J Gen Pract 2011; DOI: 10.3399/ bjgp11X548974.

25. van lerland $Y$, van Veen $M$, Huibers $L$, et al. Validity of telephone and physical triage in emergency care: the Netherlands Triage System. Fam Pract 2011; 28(3): 334-341.

26. Thomson S, Osborn R, Squires D, Reed SJ, eds. International profiles of health care systems. New York, NY: The Commonwealth Fund, 2011

27. Donders AR, van der Heijden GJ, Stijnen T, Moons KG. Review: a gentle introduction to imputation of missing values. J Clin Epidemiol 2006; 59(10): 1087-1091.

28. Thompson MJ, Ninis N, Perera R, et al. Clinical recognition of meningococcal disease in children and adolescents. Lancet 2006; 367(9508): 397-403.

29. Riordan FA, Thomson AP, Sills JA, Hart CA. Who spots the spots? Diagnosis and treatment of early meningococcal disease in children. BMJ 1996 313(7067): 1255-1256.

30. Sorensen HT, Moller-Petersen J, Krarup HB, et al. Diagnostic problems with meningococcal disease in general practice. J Clin Epidemiol 1992; 45(11). 1289-1293

31. Nadel S, Britto J, Booy R, et al. Avoidable deficiencies in the delivery of health care to children with meningococcal disease. J Accid Emerg Med 1998; 15(5): 298-303

32. Najaf-Zadeh A, Dubos F, Aurel M, Martinot A. Epidemiology of malpractice lawsuits in paediatrics. Acta Paediatr 2008; 97(11): 1486-1491.

33. Najaf-Zadeh A, Dubos F, Pruvost I, et al. Epidemiology and aetiology of paediatric malpractice claims in France. Arch Dis Child 2011; 96(2): 127-130.

34. Thompson M, Mayon-White R, Harnden A, et al. Using vital signs to assess children with acute infections: a survey of current practice. Br J Gen Pract 2008; DOI: 10.3399/bjgp08X279689.

35. Verbakel JY, Van den Bruel A, Thompson M, et al. How well do clinical prediction rules perform in identifying serious infections in acutely ill children across an international network of ambulatory care datasets? BMC Med 2013; 11: 10.

36. Moons KG, Kengne AP, Grobbee DE, et al. Risk prediction models: II. External validation, model updating, and impact assessment. Heart 2012; 98(9): 691-698.

37. Cals JW, Butler CC, Hopstaken RM, et al. Effect of point of care testing for $C$ reactive protein and training in communication skills on antibiotic use in lower respiratory tract infections: cluster randomised trial. BMJ 2009; 338: b1374.

38. Cals JW, Chappin FH, Hopstaken RM, et al. C-reactive protein point-ofcare testing for lower respiratory tract infections: a qualitative evaluation of experiences by GPs. Fam Pract 2010; 27(2): 212-218.

39. Van den Bruel A, Thompson MJ, Haj-Hassan T, et al. Diagnostic value of laboratory tests in identifying serious infections in febrile children: systematic review. BMJ 2011: 342: d3082 


\section{Appendix 1. Grouping of alarm signs for serious infection}

Grouped alarm signs

las coded in the GPC-database

Total selection of alarm signs

Parental concern

Parental concern

IIl appearance Clinician's instinct something is wrong

Clinically ill appearance

$\begin{array}{ll}\text { ABC-instability } & \text { ABC-instability } \\ \text { Unconsciousness } & \text { Unconsciousnes }\end{array}$

Drowsy Child is drowsy

Somnolence

Reactivity/functional status (decreased)

Hypotonia

Inconsolable Child is inconsolable

Irritability

Changed crying pattern

Child is moaning

\begin{tabular}{|c|c|}
\hline Abnormal circulation & $\begin{array}{l}\text { Abnormal skin colour (pale, mottled, ashen) } \\
\text { Capillary refill time }>2 \text { seconds } \\
\text { Tachycardia }\end{array}$ \\
\hline Cyanosis & $\begin{array}{l}\text { Cyanosis } \\
\text { Oxygen saturation }<95 \%\end{array}$ \\
\hline Shortness of breath & $\begin{array}{l}\text { Shortness of breath } \\
\text { Nasal flaring } \\
\text { Rapid breathing } \\
\text { Changed breathing pattern }\end{array}$ \\
\hline Meningeal irritation & $\begin{array}{l}\text { Meningeal irritation } \\
\text { Neck stiffness } \\
\text { Bulging fontanelle }\end{array}$ \\
\hline Neurological signs & $\begin{array}{l}\text { Focal neurological signs } \\
\text { Paresis/paralysis } \\
\text { Seizures/fits }\end{array}$ \\
\hline Vomiting and diarrhoea & $\begin{array}{l}\text { Vomiting ( }>2 \text { times in disease period) } \\
\text { Diarrhoea ( }>2 \text { times in disease period) }\end{array}$ \\
\hline Dehydration & $\begin{array}{l}\text { Dry mucous membranes } \\
\text { Sunken eyes } \\
\text { Decreased skin elasticity } \\
\text { Reduced urine output } \\
\text { Hypotension (APLS) } \\
\text { Poor feeding }\end{array}$ \\
\hline Extremity problems & $\begin{array}{l}\text { Swelling of limb or joint } \\
\text { Non-weight bearing limb } \\
\text { Not using an extremity }\end{array}$ \\
\hline Signs of urinary tract infection & $\begin{array}{l}\text { Urinary frequency } \\
\text { Dysuria } \\
\text { Tummy ache (without other focus for fever) }\end{array}$ \\
\hline Petechial rash & $\begin{array}{l}\text { Petechial rash } \\
\text { Purpura }\end{array}$ \\
\hline Temperature $\geq 40^{\circ} \mathrm{C}$ & Measured at home or at GP cooperative \\
\hline Duration of fever & Duration of fever $\left(>38.0^{\circ} \mathrm{C}\right)$ in days \\
\hline
\end{tabular}




\section{Appendix 2. Electronic search strategy for clinical prediction rules}

\section{Pubmed}

(Decision Trees[mesh] OR decision rule*[tw] OR decision tree*[tw] OR prediction rule*[tw] OR predictive rule*[tw] OR decision model*[tw] OR prediction model*[tw] OR predictive model*[tw] OR decision analysis model*[tw] OR risk score*[tw]) AND (child[mesh] OR child[tiab] OR children[tiab] OR pediatric*[tw] OR infant*[tw]) AND ("Arthritis, Infectious"[Mesh] OR "Bone Diseases, Infectious"[Mesh] OR "CommunityAcquired Infections"[Mesh] OR "Respiratory Tract Infections"[Mesh] OR "Sepsis"[Mesh] OR "Skin

Diseases, Infectious"[Mesh] OR "Soft Tissue Infections"[Mesh] OR "Urinary Tract Infections"[Mesh] OR "Meningitis"[Mesh] OR meningitis[tw] OR serious infection*[tw] OR serious bacterial infection*[tw] OR severe bacterial infection*[tw] OR severe infection*[tw] OR "Gastroenteritis"[Mesh]]

\section{Embase}

('Decision Tree'/de OR (ldecision* OR predict* OR risk*) NEAR/3 (rule* OR model* OR algorithm* OR aid OR score* OR tree*)):de,ab,ti) AND (child/exp OR (child* OR pediatric* OR infant*):de,ab,ti) AND ('infectious arthritis'/exp OR 'hematogenous osteomyelitis'/exp OR 'communicable disease'/exp OR 'respiratory tract infection'/exp OR 'sepsis'/exp OR 'skin infection'/exp OR 'soft tissue infection'/exp OR 'urinary tract infection'/exp OR 'meningitis'/exp OR 'gastroenteritis'/exp OR (serious* NEAR/3 infection*):de,ab,ti)

\begin{tabular}{|c|c|c|c|c|c|c|c|c|c|c|}
\hline \multirow[b]{2}{*}{$\begin{array}{l}\text { Percentiles of } \\
\text { the predicted risk }\end{array}$} & \multicolumn{2}{|c|}{$\begin{array}{c}\text { CPR4 } \\
\text { Pantell et al }{ }^{19}\end{array}$} & \multicolumn{2}{|c|}{$\begin{array}{c}\text { CPR } 5 \\
\text { Bleeker et al }{ }^{20}\end{array}$} & \multicolumn{2}{|c|}{$\begin{array}{c}\text { CPR } 6 \\
\text { Berger et al }{ }^{21}\end{array}$} & \multicolumn{2}{|c|}{$\begin{array}{c}\text { CPR } 7 \\
\text { YICSSG }\end{array}$} & \multicolumn{2}{|c|}{$\begin{array}{c}\text { CPR } 8 \\
\text { Brent et al }{ }^{23}\end{array}$} \\
\hline & $n$ & $\begin{array}{l}\text { Referral } \\
\text { to ED, \% }\end{array}$ & $n$ & $\begin{array}{l}\text { Referral } \\
\text { to ED, \% }\end{array}$ & $n$ & $\begin{array}{l}\text { Referral } \\
\text { to ED, \% }\end{array}$ & $n$ & $\begin{array}{l}\text { Referral } \\
\text { to ED, \% }\end{array}$ & $n$ & $\begin{array}{l}\text { Referral } \\
\text { to ED, \% }\end{array}$ \\
\hline $0-10^{\text {th }}$ & - & - & 893 & 6 & - & - & 7 & 0 & 610 & 6 \\
\hline $10-20^{\text {th }}$ & 65 & 20 & 228 & 8 & - & - & - & - & - & - \\
\hline $20-30^{\text {th }}$ & - & - & 744 & 5 & 1052 & 12 & - & - & - & - \\
\hline $30-40^{\text {th }}$ & 16 & 75 & 281 & 7 & - & - & 65 & 40 & - & - \\
\hline $40-50^{\text {th }}$ & 6 & 67 & 554 & 4 & 29 & 45 & - & - & 6926 & 4 \\
\hline $50-60^{\text {th }}$ & 48 & 25 & 811 & 9 & 322 & 11 & - & - & - & - \\
\hline $60-70^{\text {th }}$ & 7 & 86 & 566 & 4 & - & - & - & - & - & - \\
\hline $70-80^{\text {th }}$ & 20 & 65 & 464 & 13 & 685 & 10 & 20 & 100 & 291 & 34 \\
\hline $80-90^{\text {th }}$ & 24 & 92 & 705 & 9 & 35 & 46 & 10 & 80 & 1657 & 11 \\
\hline $90-100^{\text {th }}$ & 18 & 94 & 563 & 26 & 259 & 17 & 12 & 100 & 278 & 67 \\
\hline Total & 204 & 49 & 5809 & 9 & 2382 & 13 & 114 & 58 & 9762 & 8 \\
\hline
\end{tabular}

$C P R=$ clinical prediction rule. $E D=$ emergency department. $Y I C S S G=$ Young Infants Clinical Signs Study Group. 